leading scientists on the problematic issues of appointing of court audits by the initiative of the investigator of the prosecutor analyzed.

First, it proposed to amend article 93 of the code of Criminal Procedure of Ukraine and replace the phrase "requiring and receiving conclusions of audits and inspection acts" by "designating inspections in the form of audits".

Secondly, it suggested that law enforcement agencies should seek proposals from the public financial authority in advance to include in the plan of inspections of one or another institution.

It is accent that in order to carry out audits in healthcare institutions it is necessary to involve inspectors in this area. Namely: from the control department in the social field, who must have specific information on drug acquisition, rates of their prescription and use, standards of loading of medical equipment, technical requirements for medical equipment.

The investigating, empowered, prosecutor appeals to the public financial control body over the conduct of monitoring of public procurement in order to identify violations of the law, establish discriminatory requirements for participants, identify the facts of unfair competition, identify facts of collusion between participants, misuse of budget funds. Financial audit reports intended to provide businesses with an economic picture of the accuracy of accounting and the reliability of financial statements, and used as indirect evidence. If necessary, tracking the dynamics of crime, there is a need to verify the procurement, which results in the act.

Key words: budget crimes, healthcare, audit, financial audit, procurement review, procurement monitoring.

DOI: $10.33766 / 2524-0323.88 .226-240$

УДК 343.985

В. С. Бондар,

кандидат юридичних наук, доцент, декан факультету підготовки фахівців для підрозділів Національної поліції України Луганського державного університету внутрішніх справ імені Е. О. Дідоренка e-mail: bondarlivd@gmail.com

iD http://orcid.org/0000-0003-1552-4555

\title{
КОНЦЕПТУАЛЬНІ ЗАСАДИ ІНФОРМАЦЙНО-АНАЛІТИЧНОГО ЗАБЕЗПЕЧЕННЯ КРИМІНАЛІСТИЧНОЇ ДІЯЛЬНОСТІ
}

\footnotetext{
У статті визначено поняття, сформовано систему та конкретизовано завдання інформаційно-аналітичного забезпечення криміналістичної діяльності. Продемонстровано приклади використання аналітичних інструментів у судовоекспертній діяльності, зокрема комбінованого алгоритму порівняння ознак, який містить порівняння об' єктів методом потенційних функцій та методом контурного аналізу. Доведено, що завданнями інформаційно-аналітичного забезпечення криміналістичної діяльності $\epsilon$ надання повної, актуальної та релевантної інформації, застосування результативних методів аналізу, підвищення наочності подання результатів аналізу для слідчого та судового експерта.
} 
Ключові слова: варіативність індивідуальних ознак, дескриптори, ідентифікація, інформація, інформаційно-аналітичне забезпечення, інформаційна система, контурний аналіз, кореляція, криміналістична діяльність, метод.

Постановка проблеми. Успішне здійснення кримінального провадження та судово-експертної діяльності залежить від уміння слідчого, судового експерта, спеціаліста використовувати досягнення криміналістичної науки, зокрема втілені в розробленому вченні про інформаційно-аналітичне забезпечення криміналістичної діяльності.

Білышістю вчених-криміналістів визнається необхідність використання сучасних засобів аналізу під час досудового розслідування кримінальних правопорушень.

Водночас не всі питання названої теми вивчені достатньо докладно. На сьогодні вони потребують концептуального вирішення, розподілу, упорядкування (класифікації) наявних тут криміналістичних знань для подальшого розвитку і вдосконалення цього важливого напряму в криміналістищі та судовій експертології.

Аналіз останніх досліджень i публікацій. Історію зародження криміналістичного вчення про інформаційно-аналітичне забезпечення криміналістичної діяльності можна знайти в працях як криміналістів, так і представників інших наук - теорії оперативно-розшукової діяльності, судової експертології, адміністративного права - вітчизняних і закордонних дослідників, як-от: Ю. П. Аленіна, Е. Анушата, Ф. Г. Аміньова, Р. Л. Ахмедшина, В. В. Батищєва, Р. С. Бєлкіна, О. А. Бєлова, А. Е. Волкової, Г. Гроса, С. П. Голубятнікова, А.В. Дулова, В. А. Журавля, В. П. Захарова, І. В. Захарової, Г. О. Зоріна, Г. Г. Зуйкова, В. Б. Ісакова, А. В. Іщенка, О. М. Камінського, М. В. Карчевського, О. І. Князєва, О. С. Князькова, В. Я. Колдіна, М. А. Корнієнка, Ю. Г. Корухова, О. А. Крєстовнікова, І. М. Кузнєцова, В. К. Лисиченка, С. Д. Лук'янчикова, Н. І. Малихіної, Б. Я. Нагіленка, В. В. Тіщенка, Е. О. Разумова, В. О. Образцова, О. О. Овчинського, В. І. Пашка, А. В. Пахомова, Ю.О. Пілюкова, К. Д. Поля, О.Р. Ратінова, Б. Г. Розовського, Т. В. Толстухіної, С. В. Скриля, Ю. І. Степури, В.О. Тімченка, В.О. Федоренка, С. Н. Чурілова, В. І. Шарова, Р. Шеннона, В. Ю. Шепітька, В. У. Хатуаєва, В. Г. Хахановського, М. П. Яблокова, О. М. Яковця, С. А. Ялишева, які фактично сформували систему сучасних наукових уявлень у цій галузі. Тому сьогодні без урахування та аналітичного розгляду їхнього наукового внеску не може обійтися жодна серйозна праця 3 проблем оптимізації інформаційно-аналітичного забезпечення криміналістичної діяльності.

Водночас слід зазначити, що у вітчизняній спеціальній юридичній літературі проблеми інформаційно-аналітичного забезпечення криміналістичної діяльності взагалі та розслідування тероризму зокрема в комплексі не розглядалися.

Формування цілей. Метою статті є подальша теоретична розробка концептуальних засад інформаційно-аналітичного забезпечення криміналістичної діяльності.

Виклад основного матеріалу. Говорячи про «криміналістичну діяльність», необхідно розуміти не яку-небудь особливу сферу слідчої 
діяльності (прокурорської, судово-експертної, обліково-реєстраційної, інформаційно-аналітичної; діяльності спеціаліста-криміналіста), а й актуалізацію одного з найважливіших регулятивних механізмів їі оптимізації, переведення відповідних методологічних напрацювань із потенційного стану понять та категорій у процесуальний стан, у ході якого задається спрямованість дій та здійснюється контроль за ними [1, с. 137-141; 2, с. 112-114].

Основу криміналістичної діяльності складає врегульований нормами права пізнавальний процес, який здійснюється 3 урахуванням деяких закономірностей та певними засобами криміналістичної науки і техніки.

Інформаційно-аналітичне забезпечення криміналістичної діяльності містить дані та інформацію, характер, зміст та періодичність обробки яких залежить від мети, виду, змісту загальних та специфічних функцій розробки та контролю реалізації стратегії розвитку криміналістичної діяльності, завдань, які виникають при цьому, та, значною мірою, від того, як розуміє суб'єкт іiі здійснення значущість інформаційно-аналітичної підтримки процесуальних та інших рішень або судово-експертного дослідження.

Будь-яке поняття відповідно до правил, сформульованих логікою, характеризується змістом та обсягом. Водночас зміст поняття визначається сукупністю його істотних, необхідних і достатніх ознак [9, с. 101]. Відповідно, встановити зміст поняття інформаційно-аналітичного забезпечення криміналістичної діяльності означає з'ясувати, які ознаки є істотними, необхідними й достатніми.

Бачиться також доцільним визначити в понятті три основних компоненти, які обумовлюють будь-яку окрему криміналістичну теорію як таку:

- предмет теорії (вчення), сутність якого складають певні закономірності об'єктивної дійсності, що виділяються криміналістикою в цілому;

- об'єкти окремої теорії, які являють собою явища, речі, процеси, зв'язки та відношення, тобто ту частину предметної області, у якій мають прояв об'єктивні закономірності, що вивчаються теорією (вченням);

- метод окремої теорії (вчення), який є системою пізнавальних прийомів, що використовується як для формування самої теорії (вчення), так і для застосування теорії в практиці пізнання її предметної сфери.

Досліджене в науковій літературі питання дозволяє дійти висновку, що в багатьох роботах визначення інформаційно-аналітичного забезпечення або відсутнє, або автори ототожнюють цю дефініцію з певними елементами та засобами - криміналістичним або оперативно-розшуковим обліком чи з будьякими іншими базами даних та інформаційними системами. Логіка такого підходу цілком обгрунтована, а тому дотримана в статтях 25, 26, 27 Закону України «Про Національну поліцію».

Ю. В. Курносов та П. Ю. Конотопов під інформаційно-аналітичним забезпеченням розуміють «вид забезпечення управлінської діяльності, який реалізує функцію зворотного інформаційного зв' язку в контурі управління»[5]. Це достатньо загальне визначення (як і зауважують самі автори), яке базується на кібернетичному підході, далі уточнено так: «Система інформаційно- 
аналітичного забезпечення являє собою підсистему інформаційної інфраструктури суб'єкта управлінської діяльності, призначену для здійснення інформаційно-аналітичної діяльності в інтересах надання інформації, необхідної для вироблення адекватних управлінських рішень» [5, с. 204-205]. Подібне визначення уявляється також надто загальним та недостатньо зв'язаним.

М. В. Стафієвська вважас, що «....інформаційним аналітичним забезпеченням ... є реєстрація, узагальнення та системний аналіз інформації про господарську діяльність організації, аналітичне забезпечення - це «сукупність математичних засобів та інструментів, методики аналізу...» [8, с. 8]. Ці визначення розглядаються стосовно бухгалтерського обліку ризиків.

Ю. О. Саричев сформулював таке визначення інформаційно-аналітичного забезпечення, як: «комплекс заходів, що реалізують процеси створення інформаційних продуктів на основі використання статичних інформаційних ресурсів, проведення розрахунків, моделювання ситуацій, аналізу й синтезу документованих даних та інформації з метою підтримки прийняття рішень органами військового управління всіх рівнів» [6].

В. Д. Герасимова «Аналіз та діагностика фінансово-господарської діяльності промислового підприємства» (глосарій посібника) наводить визначення інформаційно-аналітичного забезпечення як сутності економічного аналізу, а зміст останнього - використання наукових методів для обгрунтування рішень [3].

Д. Ю. Сіротченков пропонує під інформаційно-аналітичним забезпеченням підрозділів кримінальної поліції розуміти систему заходів, що врегульована нормативно-правовими актами, спрямовану, у першу чергу, на аналіз, узагальнення, оброблення, зберігання інформації, навіть із обмеженим доступом, яка впливає на подальші рішення в діяльності ОРД, для забезпечення охорони громадян та держави тощо [7, с. 168-171].

Місце аналізу в процесі виявлення та досудового розслідування злочинів зумовило потребу у створенні профільних інформаційно-аналітичних підрозділів, наприклад: тільки в складі Національної поліції функціонують Департамент організаційно-аналітичного забезпечення та оперативного реагування, Управління кримінального аналізу, Департамент інформаційних технологій тощо.

Взаємозв'язок інформаційно-аналітичного забезпечення криміналістичної діяльності та криміналістичного обліку є очевидним.

Від розуміння сутності криміналістичного обліку, рівня організації роботи 3 іншими інформаційними ресурсами залежить система інформаційноаналітичного забезпечення криміналістичної діяльності. Обсяг криміналістично значущої інформації, яка циркулює в носіях та джерелах, постійно зростає. Це призводить до необхідності розв'язання задач, пов'язаних із налагодженням комунікацій між різними рівнями криміналістичного обліку, більш дієвого рівня використання експертних технологій для інформаційного пошуку та підрозділами, які здійснюють криміналістичну діяльність.

При формуванні інформаційної інфраструктури в підрозділі (органі, установі) найбільш складним завданням є отримання повної, актуальної та 
достовірної інформації в необхідному розрізі, що нелегко досягти стосовно функціонування складної системи протидії злочинності та судово-експертного забезпечення кримінального провадження. Найкращі методики аналізу можуть стати неприйнятними за відсутності інформації в інформаційній системі. Саме тому такою важливою $є$ роль інформаційно-аналітичного забезпечення криміналістичної діяльності.

Розбираючись із сутністю інформаційно-аналітичного забезпечення, необхідно зазначити, що термін «аналіз» має декілька значень:

1. Заключна й найбільш важлива частина інформаційної роботи, пов' язана зі встановленням взаємозв' язку між витлумаченими фактами.

2. Процес обробки інформації, пов'язаної з її узагальненням, спрощенням, концентрацією та відбором.

3. Один із етапів процесу підготовки інтелектуальної продукції. На даному рівні зібрана інформація проглядається 3 метою виявлення найбільш суттєвих фактів, порівнюється та зіставляється 3 іншими даними. Потім на підставі досвіду та знань аналітики формують висновки.

Таким чином, термін «аналітика», утворений від терміна «аналіз», означає глибоке інтелектуальне дослідження інформації, яке інакше можна назвати аналітичною роботою, котра, у свою чергу, являє собою процес впливу суб'єкта на об'єкти.

Суб'єктами аналітичної роботи виступають слідчий, керівник органу досудового розслідування, експерт-криміналіст, працівники спеціалізованих оперативних підрозділів, які виконують функції аналізу.

Об'єктами аналітичної роботи є інформація, пов'язана з подією злочину (особи, предмети, документи, явища), а також інформація, не пов' язана з подією злочину, але яка може сприяти виявленню та досудовому розслідуванню кримінальних правопорушень (дані про підприємства, організації, перетині державного кордону тощо).

Незалежно від сфери застосування аналітична робота - творча діяльність, пов' язана з оцінкою наявної інформації та підготовкою на ії основі оптимальних рішень. У слідчій діяльності - це діяльність, яка полягає в приведенні розрізнених криміналістично значущих та інших відомостей в логічно струнку та обгрунтовану систему залежностей (просторово-часових, причинно-наслідкових та інших), котрі дозволяють надати правильну оцінку як всієї сукупності фактів, так і кожному з них окремо. Під час судовоекспертних досліджень аналіз зображень об'єктів із високим ступенем варіативності також грунтується на встановленні функції взаємної кореляції, котру добувають або для всієї поверхні зображень або для окремих частин порівнюваних зображень.

Таким чином, під час роботи з інформацією з'являються дві самостійні категорії - «інформаційне забезпечення» та «аналітична робота». Процес пошуку, отримання, зберігання, накопичення, обробки та передачі інформації ії споживачеві $є$ інформаційним забезпеченням. Це поняття зовсім не розкриває себе у функціональному сенсі. У свою чергу, аналітична робота $є$ інтелектуальною складовою інформаційного забезпечення виявлення та 
досудового розслідування кримінальних правопорушень, а також судовоекспертних досліджень. У зв' язку з цим дані категорії повинні розглядатись як єдине ціле та в сукупності складати інформаційно-аналітичне забезпечення криміналістичної діяльності.

На нашу думку, інформаційно-аналітичне забезпечення криміналістичної діяльності - елемент криміналістичного обліку та аналізу, який містить таке:

- дані та первинну інформацію, отриману шляхом перетворення даних в інформаційній системі певного рівня;

- дані та отриману 3 них інформацію, які є відсутніми в інформаційній системі певного рівня, де під іншими джерелами криміналістично значущої інформації є (i/або) самостійний пошук інформації, що недостає;

- похідну (вторинну) інформацію, одержану в процесі переробки первинної інформації (з інформаційної системи та з інших джерел), яка використовується для цілей стратегічного, тактичного й оперативного аналізу;

- методи аналізу як технічний інструментарій для виконання аналітичних процедур, котрі реалізуються на базі доступних програмних пакетів, у тому числі ті, що дозволяють проводити аналіз в умовах невизначеності та за наявності неструктурованої й неповної інформації. До вказаних методів можна віднести, наприклад, контурний, кластерний, кореляційний аналіз, які використовуються в різних видах криміналістичної діяльності-слідчий, судовоекспертній та інших;

- методики аналізу об'єктів дослідження, кожна 3 яких являє собою сукупність певних методів проведення дослідження, аналітичних процедур, у процесі застосування яких досягається поставлена мета аналізу, а результати аналізу використовуються при розробці та прийнятті процесуальних рішень.

Серед інструментів аналізу, які застосовуються для опрацювання інформації, можна назвати такі:

- Ms Excel, дозволяє задіяти автоматичні методи, використовуючи Visual Basic для мови програмування додатків або останні розробки, як-от: Power Query, Power Pivot та Power Map (усі є складовою частиною пакету Office 2016);

- спеціалізоване програмне забезпечення (наприклад, Analyst Toolbox (IALEIA), Anacapa (Anacapa Sciences Inc, CШA), i2 (IBM, CШA), RICAS (ХОГA, Україна, пакет прикладних програм Matlab R2008b із використанням модуля Image Processing Toolbox)). На підставі аналізу інформації аналітик систематизує та упорядковує відомості про відносини людей, організації, ділянки місцевості, телефонні контакти тощо. Візуалізація інформації виконується шляхом складання матриць та діаграм зв'язків. Подібна робота відбувається з використанням зазначеного програмного забезпечення;

- GIS. Поліція застосовує Geomedia Professional та ArcGis як інструменти для аналізу географічних даних [4, с. 71].

Прикладом використання аналітичних інструментів у судово-експертній діяльності $є$ комбінований алгоритм зіставлення ознак, який включає порівняння об'єктів методом потенційних функцій та методом контурного аналізу. Зіставлення здійснюється за дескрипторами, які не залежить від орієнтації зображень [10, с. 16-24]. 
Рис. 1. Кодування одиничними комплексними векторами: система координат (ліворуч); опис межі об'єкта комплексними координатами, межа об'єкта позначена пунктиром (праворуч).
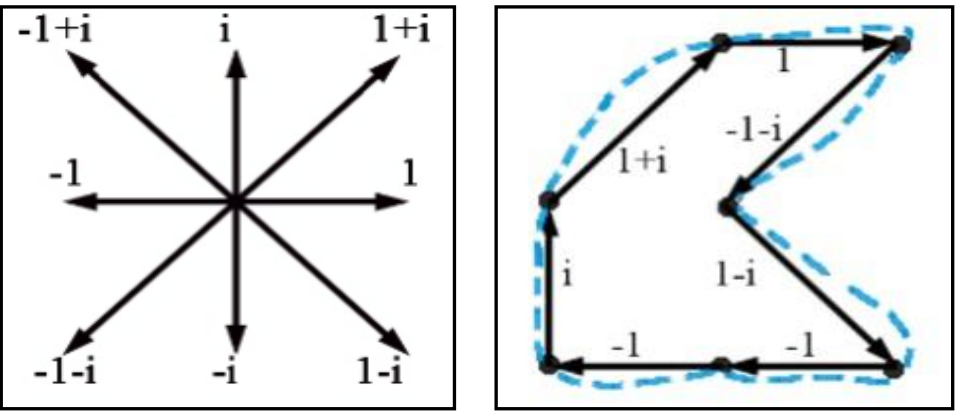

Рис. 2. Апроксимація межі ознаки комплексними векторами: виділений контур всієї ознаки (ліворуч); фрагмент контуру ознаки (праворуч).
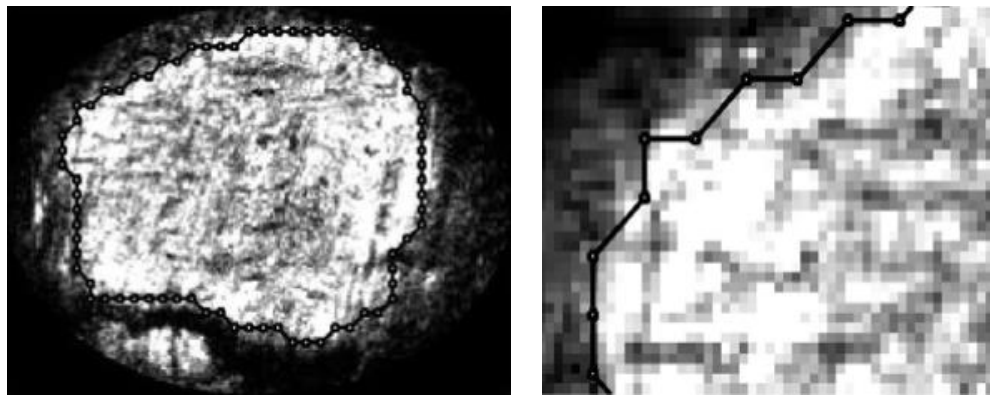

Отже, під інформаційно-аналітичним забезпеченням криміналістичної діяльності будемо розуміти комплекс первинної та вторинної внутрісистемної та позасистемної інформації, інструменти та інші методи методики їі аналізу, які надають можливість аналітику певний спектр рішень, необхідних для побудови причинно-наслідкових зв'язків.

Завданнями інформаційно-аналітичного забезпечення криміналістичної діяльності є:

- надання повної, актуальної та релевантної інформації, яка є необхідною для здійснення криміналістичної діяльності;

- застосування адекватних та результативних методів аналізу криміналістично значущої інформації;

- підвищення наочності подання результатів аналізу для слідчого та судового експерта;

- побудова процесу ефективного обміну криміналістично значущою інформацією під час досудового розслідування кримінального провадження та судово-експертного його забезпечення; 
- підвищення ефективності та швидкості прийняття процесуальних та інших рішень у результаті аналізу факторів, які впливають на криміналістичну діяльність. Прикладом такого фактору є топологічна варіативність ознак, під якою можна розуміти формування зображень слідів одного бійка з відмінними характеристиками Ейлера або різною кількістю ознак при одних і тих самих режимах обробки вихідних цифрових зображень.

На думку автора, комплекс інформаційно-аналітичного забезпечення криміналістичної діяльності повинен забезпечувати таке:

- вибір системи ключових об'єктів аналізу з метою формування складної багаторівневої характеристики тієї чи іншої події, яка враховує всі взаємозв' язки, що виникають у процесі ії розвитку;

- погодження стратегічних й тактичних задач розслідування з прийнятою системою об'єктів аналізу (час, місце, спосіб, обстановку події, слідвідображення тощо). Серед типових тактичних задач можна назвати встановлення події злочину; встановлення особи, яка вчинила злочин за залишеними нею слідами: IP-адресою, МАС-адресою, адресою електронної пошти, ідентифікатором соціальної мережі, номером банківської карти, номером телефону, інформацією про $3^{\prime}$ єднання абонента, проведенням транзакції тощо; встановлення шкоди та забезпечення іiі відшкодування; встановлення обставин вчинення злочину; доведення винності особи у вчиненні злочину тощо. Метою інформаційного аналізу у випадках, наприклад, розшуку особи, безвісти зниклої, у цілому та вибору категорій зокрема, повинен стати збір максимально повного набору ідентифікаційних даних, які мають відношення до такої особи. У якості таких даних можуть виступати а) номери мобільних телефонів, номери IMEI та IMSI; б) MAС-адреси персональних комп'ютерів, планшетів, смартфонів; г) аккаунти та паролі в соціальних мережах; г) логіни та паролі доступу в Інтернет (у тому числі WiFi тощо), інформація про використаних особою предметах з RFID-позначками, гаджетах, які мають вихід до Інтернету, інші цифрові мережі передачі даних (пульсометри, крокоміри тощо); д) аккаунти та паролі в електронній пошті, системах комп' ютерної комунікації, мережевих комп'ютерних іграх; е) номери та реквізити банківських карток, електронних платіжних систем, якими послугувалася людина, що безвісти зникла, тощо; є) проїзні документи, які використовувалися особою останнім часом; ж) позначення місць розташування (геотеги) у створених останнім часом файлах фотографій (у телефонах, планшетах, фотоапаратах, комп'ютерах), маршрутах в GPS-навігаторах;

- перетворення обраних об'єктів у форму, необхідну для їх обробки та аналізу комплексом інформаційно-аналітичного забезпечення криміналістичної діяльності;

- складання схем мережі зв' язків на кожного фігуранта;

- аналіз зв'язків об'єктів обліку - елементів інформаційної системи, отримання знань із використанням методик аналізу;

- аналітичну перевірку (прогнозування) наслідків запланованих процесуальних рішень під час досудового розслідування на предмет їх відповідності системі цільових критеріїв;

- підготовку аналітичних документів. 
У випадках розшуку безвісти зниклих за рахунок застосування різноманітних методів аналітичної обробки можливо досягнути таких результатів:

- здійснити позиціонування абонентів мобільного зв'язку на місцевості в конкретні моменти часу, що дозволить побудувати типові маршрути їхнього руху та виявити можливі аномалії поведінки (наприклад, перед моментом зникнення);

- визначити коло потенційних свідків подій, які відбувалися в певні моменти часу;

- виявити коло спілкування особи, яка зникла (друзі, соціальні мережі).

Іншими словами, можливості використання інформаційних технологій та аналітичних методів обробки великих обсягів різнорідної цифрової інформації під час досудового розслідування злочинів, пов' язаних із безвісним зникненням осіб, потенційно фактично необмежені. Сьогодні не існує перешкод для розробки конкретних алгоритмів розв'язання криміналістичних задач на базі аналізу великих обсягів інформації.

Відмінною особливістю задач інформаційно-аналітичного забезпечення криміналістичної діяльності, на думку автора, є його націленість на кінцевий результат - на підкріплене аналізом процесуальне рішення, у той час як завданням інформаційного забезпечення є постачання інформації суб'єкту розслідування.

Під час формування та впровадження інформаційно-аналітичного забезпечення криміналістичної діяльності аналітик постійно оперує показниками, адже найбільш ефективним способом опису об'єкта аналізу є його подання шляхом показників. Аналітичне забезпечення, тобто методики та методи аналізу, направлені на вимірювання показників, аналіз динаміки та прогнозування значень показників, а також контроль над досягненням їх цільових значень. Таким чином, одиницею інформаційно-аналітичного забезпечення криміналістичної діяльності є показник.

Показники, отримані шляхом обробки даних у контексті цілей та задач, наприклад, досудового розслідування серійних убивств, є важливою частиною інформації.

Дослідження обставин учинення серійних убивств дозволяє виділити такі основні види інформації, що піддається логіко-структурному аналізу, яка містить ознаки їх вчинення одними й тими ж особами та сприяє віднесенню конкретних серій убивств до тієї або іншої класифікаційної групи.

1. Судово-медична - причина та час настання смерті; характер та локалізація тілесних ушкоджень на трупах потерпілих; ознаки завдання тілесних ушкоджень після оголення тіла жертви; розсічення, повна або часткова ампутація зовнішніх та внутрішніх статевих органів; використання однотипних знарядь убивства; ознаки знущання над трупом у вигляді посмертних тілесних ушкоджень; наявність на трупі нетипових пошкоджень (ампутація пальця, носа; розсічення серця; перерізання шиї та інші). 
2. Медико-криміналістична - сліди зубів на тілах потерпілих, які утворилися при укусах; характерні сліди знарядь убивств на тілах потерпілих та знарядь розчленування на кістках та хрящах трупів та їх фрагментів.

3. Трасологічна - сліди рук на предметах обстановки та на знаряддях убивств; сліди взуття на місцях убивств; сліди зубів на недопалках; сліди транспортних засобів навколо місць виявлення трупів; сліди рублячих та ріжучих знарядь на гілках, якими маскуються трупи. У випадках, коли злочинці зв'язують руки або заклеюють рота людям, які піддалися нападам та тортурам, липкою стрічкою («скотчем») або ізоляційною стрічкою, сліди рук нападників можуть залишитись на такій стрічці; сліди-нашарування мікрочасток у вигляді волокон, які відрізняються від інших у складі тканини одягу потерпілих та мають однакове походження з мікрочастками, виявленими за іншими епізодами вбивств; мікрочастки на деталях обстановки місця події; у змісті піднігтьових лож трупів потерпілих.

4. Балістична - стріляні з одного й того ж екземпляра нарізної вогнепальної зброї: а) кулі, вилучені з тіл потерпілих, а також виявлені на місцях подій за різними епізодами вбивств; б) стріляні гільзи; в) патрони зі слідами перебування в казенній частині одного й того ж екземпляра зброї, знайдені на різних місцях убивств; г) подібність складу гомогенного металу для куль та ознаки використання однієї й тієї ж зброї для виготовлення пижів і прокладок до патронів для гладкоствольної зброї.

5. Біологічна - кров на одязі потерпілих та в змісті піднігтьових лож їхніх рук; слина на недопалках сигарет, випалених злочинцями (вони можуть знаходитися як на місці вбивства, так і на тому містині, звідки злочинець виглядав жертву); потожирова речовина на головних уборах, рукавичках, предметах одягу злочинця, на знаряддях убивств; носовий слиз на носових хустинках, які не належать потерпілим; сперма на предметах одягу, білизни та на тілах потерпілих, на тампонах з мазками з їхніх трупів; волосся на місцях подій, на тілі, у пальцях рук трупів, на їхньому одязі; частини епітеліальної тканини в піднігтьовому змісті потерпілих; кров у слідах, які утворилися в результаті травмування злочинця на місцях подій.

6. Запахова - проби повітря з місць подій; на знаряддях убивств та інших об'єктах, які не належать потерпілим; на одязі потерпілих, який контактував із одягом, руками, тілом злочинця; у слідах крові, виділень та у волоссі злочинця.

7. Технічна (конструкторсько-технологічна) - конструктивні особливості будови та технології виготовлення знарядь убивств (наприклад, атипової вогнепальної зброї шляхом розсвердлювання стволів газових пістолетів та виготовлення вкладок під них, що забезпечують стрільбу штатними патронами); пристроїв до вогнепальної зброї (саморобних глушників та пістолетів та пістолетів-кулеметів); сліди обладнання та інструментів, які використовувалися для виготовлення зазначених об'єктів.

8. Інша криміналістична - розташування в укритих місцях, які дозволяють попередньо спостерігати за жертвою, а потім непомітно та раптово нападати на неї; знаходження місць подій поблизу зупинок транспорту; характерні ознаки місць приховання трупів жертв, які дають підставу передбачати добре знання злочинців цієї місцевості та інші; наявність групи суб'єктивних портретів, 
подібних один одному; обличчя ймовірних злочинців, складених художниками-криміналістами методом суб'єктивного рисованого портрету або створення «фотороботу» за показаннями потерпілих, які залишилися в живих, або свідків; збіг часу вбивств; учинення злочинів в одні й ті самі дні тижня тощо.

Висновки. На підставі інформаційної сутності процесу розслідування запропоновано визначення інформаційно-аналітичного забезпечення криміналістичної діяльності, яка містить таке:

- дані та первинну інформацію, отриману шляхом перетворення даних в інформаційній системі певного рівня;

- дані та отриману з них інформацію, які є відсутніми в інформаційній системі певного рівня, де під іншими джерелами криміналістично значущої інформації є (i/або) самостійний пошук інформації, що недостає;

- похідну (вторинну) інформацію, одержану в процесі переробки первинної інформації, що надійшла 3 інформаційної системи та 3 інших джерел, яка використовується для цілей стратегічного, тактичного й оперативного аналізу;

- методи аналізу як технічний інструментарій для виконання аналітичних процедур, котрі реалізуються на базі доступних програмних пакетів, у тому числі такі, що дозволяють проводити аналіз в умовах невизначеності та за наявності неструктурованої та неповної інформації;

- методики аналізу об'єктів дослідження, кожна 3 яких являє собою сукупність певних методів проведення дослідження, аналітичних процедур, у процесі застосування яких досягається поставлена мета аналізу, а результати аналізу використовуються при розробці та прийнятті процесуальних рішень.

Обгрунтовано, що комплекс інформаційно-аналітичного забезпечення криміналістичної діяльності повинен забезпечувати:

- вибір системи ключових об'єктів аналізу;

- погодження стратегічних й тактичних задач розслідування з прийнятою системою об'єктів аналізу (час, місце, спосіб, обстановку події, слідвідображення тощо);

- перетворення обраних об'єктів у форму, необхідну для їх обробки та аналізу комплексом інформаційно-аналітичного забезпечення криміналістичної діяльності;

- складання схем мережі зв' язків на кожного фігуранта;

- аналіз зв'язків об'єктів обліку - елементів інформаційної системи, отримання знань із використанням методик аналізу;

- аналітичну перевірку (прогнозування) наслідків запланованих процесуальних рішень під час досудового розслідування на предмет їх відповідності системі цільових критеріїв;

- підготовку аналітичних документів.

Визначені основні види інформації, що піддається логіко-структурному аналізу, яка містить ознаки їх вчинення одними й тими ж особами, а також сприяє віднесенню конкретних серій убивств до тієї або іншої класифікаційної групи. 
Отже, подальші дослідження доцільно спрямувати на розробку криміналістичної характеристики злочинів як інструменту аналізу.

\section{Використані джерела:}

1. Бондар В. С. Інформаційно-аналітичне забезпечення криміналістичної діяльності в процесі досудового розслідування кримінальних правопорушень, пов'язаних з тероризмом. Науковий Вісник Ужгородського національного університету. Серія: Право. 2015. Вип. 33 (2). С. 137-141.

2. Бондар В. С. Криміналістична діяльність: визначення поняття. Науковий вісник Херсонського державного університету. Серія Юридичні науки. 2016. Вип. 6. Т. 3. С. 112-117.

3. Герасимова В. Д. Анализ и диагностика финансово-хозяйственной деятельности промышленного предприятия. М.: «КНОРУС», 2011. 360 с.

4. Зачек О. І., Дмитрик Ю. І. Використання оперативного, тактичного та стратегічного аналізу у боротьбі зі злочинністю. Інформаиійно-аналітичне забезпечення діяльності підрозділів кримінальної поліції: збірник наукових статей за матеріалами доповідей Всеукраїнського науково-практичного семінару 23 березня 2018 року / упорядники А. В. Баб'як, В. В. Сеник, Т. В. Магеровська. Львів: ЛьвДУВС, 2018. С. 69-76.

5. Курносов Ю. В., Конотопов П. Ю. Аналитика: методология, технология и организация информационно-аналитической работы. М.: РУСАКИ, 2004. 512 с.

6. Саричев Ю. О. Теоретичний підхід до інформаційного забезпечення управління у воєнній сфері. Вісник НАДУ при Президентові України (Серія «Державне управління»). 2016. № 4. С. 153-160.

7. Сіротченков Д. Ю. Інформаційно-аналітичне забезпечення оперативнорозшукової діяльності: окремий аспект. Інформаційно-аналітичне забезпечення діяльності підрозділів кримінальної поліції: збірник наукових статей за матеріалами доповідей Всеукраїнського науково-практичного семінару 23 березня 2018 року / упорядники А.В.Баб'як, В. В. Сеник, Т. В. Магеровська. Львів: ЛьвДУВС, 2018. С. 168-171.

8. Стафиевская М. В. Бухгалтерский учет рисков в коммерческих организациях. Международный бухгалтерский учет. 2014. № 35. С. 16-29.

9. Українське кримінальне право. Загальна частина: підручник / за ред. В. О. Навроцького. К.: Юрінком Інтер, 2013. 712 с.

10. Федоренко В. А., Корнилов М. В. Оценка схожести следов бойков огнестрельного оружия их цифровым изображениям. Информационные технологии и вычислительные системы. 2015. № 3. С. 16-24.

\section{References:}

1. Bondar, V. S. (2015). Informatsiyno-analitychne zabezpechennya kryminalistychnoyi diyal'nosti $\mathrm{v}$ protsesi dosudovoho rozsliduvannya kryminal'nykh pravoporushen', pov"yazanykh z teroryzmom. Naukovyy visnyk Uzhhorods'koho natsional'noho universytetu. Seriya: Pravo - Scientific Bulletin of Uzhgorod National University. Series: Right, 33 (2), 137-141 [in Ukrainian].

2. Bondar, V. S. (2016). Kryminalistychna diyal'nist': vyznachennya ponyattya. Naukooyy visnyk Khersons'koho derzhavnoho universytetu. Seriya Yurydychni nauky - Scientific Bulletin of Kherson State University. Legal Sciences Series, 6, 112-117. [in Ukrainian].

3. Gerasimova, V. D. (2011). Analiz i diagnostika finansovo-khozyaystvennoy deyatel'nosti promyshlennogo predpriyatiya. Moskva: KNORUS. [in Russian].

4. Zachek, O. I., \& Dmytryk, YU. I. (2018). Vykorystannya operatyvnoho, taktychnoho ta stratehichnoho analizu $\mathrm{u}$ borot'bi zi zlochynnistyu. Informatsiino-analitychne zabezpechennia diialnosti pidrozdiliv kryminalnoi politsii: zbirnyk naukovykh statei za materialamy 
dopovidei Vseukrainskoho naukovo-praktychnoho seminaru 23 bereznia 2018 roku - Information and analytical support of the activities of the units of the criminal police: a collection of scientific articles based on the materials of the reports of the All-Ukrainian scientific and practical seminar on March 23, 2018. A. V. Bab"yak, V. V. Senyk, T. V. Maherovs'ka (Eds.). Lviv: LvVDUVS, 69-76. [in Ukrainian].

5. Kurnosov, YU. V., \& Konotopov, P. YU. (2004). Analitika: metodologiya, tekhnologiya i organizatsiya informatsionno-analiticheskoy raboty Moskva: RUSAKI [in Russian].

6. Sarychev, YU. O. (2016). Teoretychnyy pidkhid do informatsiynoho zabezpechennya upravlinnya u voyenniy sferi. Visnyk NADU pry Prezydentovi Ukrayiny (Seriya «Derzhavne upravlinnya») - NADU Bulletin under the President of Ukraine (Public Administration Series), 4, 153-160. [in Ukrainian].

7. Sirotchenkov, D. YU. (2018). Informatsiyno-analitychne zabezpechennya operatyvno-rozshukovoyi diyal'nosti: okremyy aspect. Informatsiino-analitychne zabezpechennia diialnosti pidrozdiliv kryminalnoi politsii: zbirnyk naukovykh statei za materialamy dopovidei Vseukrainskoho naukovo-praktychnoho seminaru 23 bereznia 2018 roku - Information and analytical support of the activities of the units of the criminal police: a collection of scientific articles based on the materials of the reports of the All-Ukrainian scientific and practical seminar on March 23, 2018. A. V. Bab"yak, V. V. Senyk, T. V. Maherovs'ka (Eds.). Lviv: LvVDUVS, 168-171. [in Ukrainian].

8. Stafiyevskaya, M. V. (2014). Bukhgalterskiy uchet riskov v kommercheskikh organizatsiyakh. Mezhdunarodnyy bukhgalterskiy uchet - International Accounting, 35, 16-29. [in Russian].

9. Navrots'kyy, V. O. (2013). Ukrayins'ke kryminal'ne pravo. Zahal'na chastyna. V. O. Navrots'kyy (Ed.) Kyiv: Yurincom Inter. [in Ukrainian].

10. Fedorenko, V. A., \& Kornilov, M. V. (2015) Otsenka skhozhesti sledov boykov ognestrel'nogo oruzhiya ikh tsifrovym izobrazheniyam. Informatsionnyye tekhnologii $i$ vychislitel'nyye sistemy - Information Technology and Computing Systems, 3, 16-24. [in Ukrainian].

Стаття надійшла до редколегії 19.11.2019

Бондарь В. С., кандидат юридических наук, доцент, декан факультета подготовки специалистов для подразделений Национальной полиции Украины

Луганского государственного университета

внутренних дел имени Э. А. Дидоренко (г. Северодонецк, Украина)

\section{КОНЦЕПТУАЛЬНЫЕ ОСНОВЫ ИНФОРМАЦИОННО-АНАЛИТИЧЕСКОГО ОБЕСПЕЧЕНИЯ КРИМИНАЛИСТИЧЕСКОЙ ДЕЯТЕЛЬНОСТИ}

В статье определено понятие, сформирована система и конкретизированы задачи информационно-аналитического обеспечения криминалистической деятельности. Продемонстрированы примеры использования аналитических инструментов в судебно-экспертной деятельности, например, комбинированного алгоритма сравнения признаков, который включает сравнение объектом методом 
потенциальных функций и методом контурного анализа. Доказано, что задачами информационно-аналитического обеспечения криминалистической деятельности является предоставление полной, актуальной и релевантной информации, применение результативных методов анализа, повышение наглядности подачи результатов анализа для следователя и судебного эксперта.

Ключевые слова: вариативность индивидуальных признаков, идентификация, информация, информационно-аналитическое обеспечение, информационная система, контурный анализ, корреляция, криминалистическая деятельность, метод.

Bondar V.,

Candidate of Law, Associate Professor

Dean of the Faculty of specialist training for subdivisions National Police

Luhansk State University

Internal Affairs named after E. O. Didorenko

(Sievierodonetsk, Ukraine)

\section{CONCEPT, SYSTEM AND TASKS OF INFORMATION AND ANALYTICAL SUPPORT OF CRIMINALISTICS ACTIVITY}

The purpose of the article is to define the concept, form the system and specify the tasks of information and analytical support of forensic activity.

Methodological basis is a system of methods, techniques and means of scientific knowledge, which in such a quality is a complex of methods and approaches: system analysis, structural and functional analysis, as well as logical rules for formulating concepts.

The article defines the concept, formed the system and specified the tasks of information and analytical support of forensic activity. It is substantiated that information and analytical support of forensic activity includes data and primary information obtained by transformation of data in the information system of a certain level, information obtained in the process of processing of primary information used for the purposes of strategic, tactical and operational analysis, methods and methods of analysis as a technical toolkit for performing analytical procedures in the course of which the goal of the analysis is achieved. Examples of the use of analytical tools in forensic activities have been demonstrated, including a combined feature comparison algorithm that includes the comparison of objects by potential function and contour analysis. It is proved that the tasks of information and analytical support of forensic activity is to provide complete, relevant and relevant information, use of effective methods of analysis, increase the clarity of presentation of analysis results for the investigative and forensic expert.

It is substantiated that the complex of information and analytical support of forensic activity should provide a choice of the system of key objects of analysis, coordination of strategic and tactical tasks of investigation with the adopted system of objects of analysis (time, place, method, situation of the event, footprint, etc.); transformation of selected objects into the form necessary for their processing and analysis by a complex of information and analytical support of forensic activity; drawing up the communication network diagrams for each person involved; analysis of the relations of accounting objects - elements of the information system, obtaining knowledge using the methods of analysis; analytical verification (prediction) of the consequences of the planned procedural decisions during the 
pre-trial investigation for their compliance with the system of target criteria; preparation of analytical documents.

Key words: variability of individual characteristics, descriptors, identification, information, information system, contour analysis, correlation, method, pattern recognition.

DOI: $10.33766 / 2524-0323.88 .240-250$

УДК 343.98

А. В. Коваленко,

кандидат юридичних наук, старший викладач кафедри державно-правових дисциплін Луганського державного університету внутрішніх справ імені Е. О. Дідоренка (м. Сєвєродонецьк, Україна) e-mail: new4or@gmail.com iD http://orcid.org/0000-0003-3665-0147

\section{СИТУАЦІЙНА ОБУМОВЛЕНІСТЬ ЗБИРАННЯ, ДОСЛІДЖЕННЯ ТА ВИКОРИСТАННЯ ДОКАЗІВ У КРИМІНАЛЬНОМУ ПРОВАДЖЕННІ}

Стаття присвячена обгрунтуванню ситуаційної обумовленості збирання, дослідження та використання доказів у кримінальному провадженні. Автором проаналізовано основні підходи до розуміння терміна «слідча ситуація» та особливості застосування даного поняття як категорії криміналістичної тактики й методики. Розглянуто інші види криміналістично значущих ситуацій у кримінальному провадженні, зокрема ситуації слідчої (розшукової) дії, техніко-криміналістичні ситуації, експертні ситуації тощо. Запропоновано шляхи вдосконалення криміналістичних рекомендацій за рахунок використання науковцями закономірностей ситуаційної обумовленості доказування в кримінальному провадженні. Визначено пріоритетні напрямки дослідження ситуаційної обумовленості доказування в кримінальному провадженні.

Ключові слова: криміналістична ситуалогія, ситуація, слідча ситуація, доказування, криміналістичні рекомендації.

Постановка проблеми. Прийняття будь яких рішень у кримінальному провадженні, у тому числі щодо застосування тих чи інших техніко- та тактикокриміналістичних засобів збирання й дослідження доказів, зазвичай обумовлено обставинами, у яких приймається відповідне рішення. Сукупність таких обставин, зокрема вся інформація про кримінальне правопорушення, котра наявна в слідства на конкретному етапі розслідування, інші внутрішні та зовнішні фактори, що впливають на розслідування, формують конкретну ситуацію в провадженні, яка і визначає модель поведінки слідчого. Наведене дає підстави говорити про ситуаційну обумовленість кримінально-процесуального доказування, загальні закономірності якої потребують наукового дослідження.

Аналіз останніх досліджень i публікацій. Теоретичні основи криміналістичної ситуалогії були розроблені О. Я. Баєвим, Р. С. Бєлкіним, О. М. Васильєвим, Т. С. Волчецькою, І. Ф. Герасімовим, Г. Л. Грановським, (C) Коваленко А. В., 2019 